\title{
Impact of Firms' Profitability on Environmental Performance: Evidence from Companies in India
}

\author{
Vasanth Vinayagamoorthi
}

Ph.D Research Scholar in Management, Department of Commerce and Financial Studies, Bharathidasan University, Tiruchirappalli - 620 024, Tamilnadu, India

Email: cavasanth@gmail.com

Selvam Murugesan

Professor and Head, Department of Commerce and Financial Studies, Bharathidasan University, Tiruchirappalli - 620 024, Tamilnadu, India

\section{Lingaraja Kasilingam}

Ph.D Research Scholar in Management, Department of Commerce and Financial Studies, Bharathidasan University, Tiruchirappalli - 620 024, Tamilnadu, India

\section{Doi:10.5901/mjss.2015.v6n1p109}

\begin{abstract}
The issues relating to the environment are the main talking points in the present world. Many natural calamities like global warming, cautioned the world community to protect the globe from the environmental degradation. This situation compelled the corporates to involve themselves in responsible activities and disclose their environmental performance in their Annual Report. Many research works explain the different dimensions of environment issue. This study makes an attempt to analyse the impact of profitability on environmental performance of the firm. The analysis has made use of descriptive statistics, correlation, and regression analysis. The results found that the profitability variables like ROA, ROE, and ROS create the positive impact on energy intensity (proxy of environmental performance) of the sample firms. At the same time, one profitability variable such as ROCE recorded negative impact on El. This paper offers useful suggestions to the corporates to reduce the level of energy intensity and to utilize the companies' capital for sustainable performance.
\end{abstract}

Keywords: Environmental Performance, Firm's Profitability, Energy Intensity, Sustainable Performance

\section{Introduction of the Study}

The issues relating to environment are considered as the talking points in the modern world. The environment issues are degradation of natural resources, growing trend of population level of pollution etc. In a normal life, majority of people realize that the poor management of the environment exists in different walks of life (Stern, P. C., 1992). These worst situations cautioned the world to take appropriate steps for changing the human behaviour and to ensure socially responsible action. Besides, the Government has been urged to develop the knowledge and awareness on the environment and socially responsible activities among the people. It is to be noted that for these reasons, the corporates started to disclose the ethical basis of their corporate activities to attract the people by creating reputation for the companies' product as environment friendly product, and to enhance the investors' confidence (Cormier and Magnan, 2003). At present, the firm has to pay penalties and fine due to the environmental accident and violation of the regulation relating to environment. There is an increasing number of research works on environmental and financial performance. Moreover, the researchers do analyze the relationship between financial and environmental performance. The main aim of this type of research is to improve the financial performance of the firm without compromising on environmental protection. The main inputs for the development and growth of economy are mainly by the utilization of energy resources. In the world of today, the level of $\mathrm{CO}_{2}$ emission is raised from the uncontrolled utilization of energy. Many studies and reports show that one of the main reasons for the increasing level of pollution is industrialization and globalization of the world. To protect the world from emission, it is not possible to avoid the industrialization and economic growth. In this situation, there is need for discharging responsible business by protecting the environment from the emission. The profit is an effective tool for measuring the efficiency of the business. One of the major portions of the countries' GDP depends 
on the profitability of the industrial growth of the country. Hence it is important for every company to maintain or to increase the level of profit. Corporates take necessary steps to prevent the degradation of the global environment by controlling the level of pollution without affecting the profitability of the company. In other words, it is essential that when the company earns more profit from the operation of the business, it should spend a portion of amount towards environmental protection. In India, the amended Companies Act 2013 also insists that a profitable company should spend sufficient amount towards the Socially Responsible Activity also. The regulators, policy makers, stake holders, and corporates do emphasise both profitability and environmental performance. Here this research proposes to study the profitability of company and the related problem of level of energy intensity.

\section{Review of Literature}

The existing literatures relating to the area of environmental performance, energy intensity, and financial performance are briefly reviewed.

G.Y. Qi et al (2014) examined the effect of firms' environmental performance and financial performance of the Chinese firms. Descriptive statistics, correlation analysis and regression analysis were applied. It was found that the environmental performance influenced the financial performance of the company. Priyanka Aggarwal (2013) reviewed the research studies relating to the effect of environmental performance and financial performance. It was found that out of 18 studies, 16 studies used environmental performance as an independent variable. Eight studies showed positive relationship, three showed negative relationship and five studies provided mixed or no significant results. Ruchika Bammi (2013) analysed the difference between financial performance in Indian companies with different levels of emission. The emission intensity was used as proxy for environmental performance while Profit before Interest and Tax, Return on capital employed, and market return were used to measure the financial performance. Khalid Ahmed and Wei Long (2012) observed that there was relationship between the economic growth, $\mathrm{CO}_{2}$ emission, consumption of energy, density of population and trade liberalization. This study identified that the inverted $\mathrm{U}$ shape relationship arose between the level of $\mathrm{CO}_{2}$ emission and economic growth. Hiroki Iwata and Keisuke Okada (2011) investigated the effect of environmental performance on financial performance and found that waste emissions did not have significant effect on financial performance and the greenhouse gas reduction leads to an increase in financial performance in clean industries. According to Santosh Kumar Sahu and Krishnan Narayanan (2011), the firm size and nature of ownership were the major determinants of energy intensity and found that there was non - linear relationship among energy intensity and firm size. Goldar B (2010) identified the factors influencing energy intensity in firm level by considering variables such as firm size, age of the firm, export intensity, advertisement intensity, and R\&D intensity. It was found that changes in technology, R\&D intensity, firm size and firm location were more significant in determining the energy intensity. According to Elif Akbostanci et al. (2009), there was co- integration and $\mathrm{N}$-shape relationship among the income and environmental quality. This study considered the $\mathrm{CO}_{2}$ emission, air pollution and per capita income of Turkey. The researcher suggests that every country should develop policy at local and national level to reduce the level of pollution by not considering the level of income. Toshiyuki Sueyoshi and Mika Goto (2009) found significant relationship between expenditure for environment and financial performance. Variables like Return on Assets, Net Income to Operating Revenue, Debt to equity Ratio, Firm Size (logarithmic transformation of Total Assets), Environmental protection facilities and Environmental protection by the US electric utility industry were used for the analysis. Aly Salama (2005) found that there was positive relationship between Corporate Environmental Performance and Corporate Financial Performance and recommended that managers should devote considerable attention to environmental stakeholders to attract the investors who target environmentally admirable companies. Mark A. Cohen Scott and A. Fenn, Shameek Konar (1997) found that there was relationship between environmental and financial performance of S\&P 500 (US) companies. This study classified the companies into two groups, on the basis of high polluter and low polluter companies. This study found that environmental leaders in an industry-balanced portfolio, were found to do better than environmental laggards. David I. Stern et al. (1996) found inverted $U$ - shape relationship between level of degradation in the environment and income per capita.

The literature review reveals that with the exception of a few, no wide-ranging study deals with the analysis of relationship between environmental and financial performance around the world. Especially in India, there is need to study this area. The present study is an attempt to take the step forward towards the research dealing with environment and financial performance.

\section{Statement of the Problem}

The concept of Environmental Performance (EP) is an effective tool for judging the sustainable consumption of natural 
resources by the organization. In the current situation, majority of corporates do adopt the environment management system for better competiveness of the business. The issues about the environmental performance are being focused by the corporates while framing the business strategy. The stakeholders of firms do have awareness about the social responsibility of the firm. The corporates are compelled to disclose their environmental performance. The problem is that some of the corporates do not show their willingness to spend the required amount for protecting the environment. Such corporates consider that the expenses toward the environmental performance are cost burdens to the firm. But other corporates considered that the amount spent to protect the environment or to maintain the environmental performance is good for the company to promote its reputation. As a result, some of the companies do voluntarily follow the ethical activities and promote new technology to optimize the energy consumption. Also the another major problem is that the low profitable companies do voluntarily involve in ethical activities and concentrate on the optimum consumption of energy but high profitable companies swallow the resources and enjoy more profit. Hence there is need for strict regulation to maintain the contribution by the corporates towards environment protection. Further, there is a need for equilibrium among the companies to protect environment and better consumption of resources. Against this background, the present study on the analysis of the impact of profitability on environmental performance of the firm was carried out.

\section{Importance of the Study}

The environmental performance of companies is affected by the profitability of the firm. The main aim of the corporates is to earn profit because it is necessary for the future development and the extension of business. It is possible for the companies to earn profit only when they fulfill the expectations of the stakeholders. This study explains the status of the sample companies towards the environmental performance. This research evaluates the contribution of companies' profit towards protecting the environment. In the light of this study, the corporate manager may be helped to know the present contribution of the company towards the environmental and ethical activities. The study may help to initiate appropriate steps to maintain the level of environmental performance. This leads to reduction of environmental scarcity and to optimize the utilization of resource for production. Further, this study may help stakeholders to identify the companies involved in environmentally responsible activities. Investors who are willing to invest their money in socially responsible firms may be able to assess the environmental performance of the company. Also this creates good reputation among all the stakeholders and leads to increase in market value. Moreover, this study would help the policy makers to frame workable regulations to improve the activities by corporates for ecology protection. Hence this study is considered important in the current situation.

\section{Objectives of the Study}

The following are the objectives of the present study.

- To describe the nature of profitability and environmental performance of the firm.

- To examine the relationship between profitability of the firm and firm's environmental performance.

- To study the impact of firm's profitability on environmental performance of the firm.

\section{Hypothesis of the Study}

The following Null Hypothesis was framed and tested in this study

$\mathrm{NH}_{1}$ : There is no impact of profitability variables on environmental performance of the firm.

\section{Research Design}

The previous literatures relating to this study followed the different measures to examine the impact of profitability on the environmental performance of the firm. As followed by G.Y.Qi et. al. (2014) and Santosh Kumar Sahu \& Krishnan Narayanan, (2011), this study adopt the research design as follows

\subsection{Sample Selection}

Companies listed in Bombay Stock Exchange (BSE) - S\&P BSE 500 Index were adopted for the study. This index covers 20 major industries of the economy and $93 \%$ of the total market capitalization of BSE. But the required data were available only for 191 companies. Hence the sample size was limited to 191 Companies of S\&P BSE 500 Index. 


\subsection{Source and Collection of Data}

The study mainly depended on secondary data. The required data were collected from the annual financial statements of sample companies, found in CMIE Prowess Online Corporate Database. The other relevant data for this study were collected from various books, journals, magazines, websites etc.

\subsection{Period of Study}

For the purpose of collecting required data, the present study covered a period of 10 years from $1^{\text {st }}$ April 2004 to $31^{\text {st }}$ March 2014.

\subsection{Variables adopted in the study}

Table - 1 displays the variables used in this study, to examine the impact of profitability on environmental performance of the firm.

Table - 1: List of Variables adopted in the study

\begin{tabular}{|c|c|c|c|c|}
\hline Indicators & Sub-Indicators & Abbreviation & Nature of Variable & Sources \\
\hline $\begin{array}{c}\text { Environmental } \\
\text { Performance } \\
\text { (Energy Intensity Ratio) }\end{array}$ & $\begin{array}{c}\text { Power and Fuel } \\
\text { Expenses }\end{array}$ & El & Dependent & $\begin{array}{l}\text { G.Y.Qi et. al. (2014), Amy Tung et. al. } \\
\text { (2014), and Santosh Kumar Sahu \& } \\
\text { Krishnan Narayanan, (2011) }\end{array}$ \\
\hline \multirow{4}{*}{ Firms' Profitability } & Return on Assets & $\mathrm{ROA}$ & Independent & \multirow{4}{*}{$\begin{array}{l}\text { Hart and Ahuja (1996), Marcus Wagner, } \\
\text { M. (2005), Hiroki Iwata and Keisuke } \\
\text { Okada (2011), G.Y. Qi, et. al. (2014) }\end{array}$} \\
\hline & Return on Equity & ROE & Independent & \\
\hline & $\begin{array}{l}\text { Return on Capital } \\
\text { Employed }\end{array}$ & ROCE & Independent & \\
\hline & Return on Sales & ROS & Independent & \\
\hline
\end{tabular}

\subsection{Tools used for the Analysis}

For the purpose of testing the hypothesis of this study, the followings tools were used.

\subsubsection{Descriptive Statistics}

Descriptive Statistics covers mean, minimum, maximum and standard deviation. Mean provides the average value of the selected variables. Minimum and maximum help us to understand the ups and down of the data adopted. The variance of the result can easily be understood by the value of Standard Deviation. In other words, standard deviation refers to the deviation of the value from the mean values.

\subsubsection{Correlation}

In order to estimate the degree of relationship between two or more variables, the cross correlation is an important measurement. It measures the strength of the relationship among two variables. The linear association between the variables is measured by the value of coefficient. The following is the equation used to identify the coefficient of correlation.

$$
\begin{aligned}
& r=\frac{n\left(\sum x y\right)-\left(\sum x\right)\left(\sum y\right)}{\sqrt{n\left(\sum x^{2}-\left(\sum x\right)^{2}\right)\left(n \sum y-(\Sigma y)^{2}\right)}} \\
& \text { Where, } \\
& N=\text { Number of observations } \\
& \sum x=\text { Dependent variables, } \\
& \sum y=\text { Independent variables }
\end{aligned}
$$

\subsubsection{Ordinary Least Square Regression}

The unknown parameters are estimated in the linear regression model by using Ordinary Least Squares (OLS) method. Also, this is one of the simplest methods to fit a function with the data. The estimated regression equation is

$$
Y=\beta_{0}+\beta_{1} X_{1}+\beta_{2} X_{2}+\beta_{3} D+\hat{e}
$$


The residual, $\hat{e}$, is the difference between the actual $Y$ and the predicted $Y$ and has a zero mean. In other words, OLS calculates the slope coefficients so that the difference between the predicted $Y$ and the actual $Y$ is minimized. (The residuals are squared in order to compare negative errors to positive errors more easily).

\subsection{Limitation of the Study}

The following are the select limitations of the study.

1. Sample companies were selected only from S\&P BSE 500 Index

2. On the basis of data availability, the number of sample companies was finalized.

3. The limitations associated with statistical tools, apply to this study also.

4. All the suggestions and findings were based on sample companies.

\section{Analysis of Nature of Variables, Relationship and Impact of Profitability on Environmental Performance of the Firm}

The main aim of this study was to analyse the impact of profitability on environmental performance of the firm. On the basis of the purpose, the analysis of this research is classified as follows:

1. Nature of selected profitability variables and El of sample firms

2. Relationship among the selected profitability variables and El of sample firms

3. Impact of the selected profitability variables on El of sample firms

\subsection{Nature of selected profitability variables and El of sample firms}

Table - 2 describes the results of descriptive statistics, actual value and changes in value of sample profitability variables and El of sample firms during the study period from $1^{\text {st }}$ April 2005 to $31^{\text {st }}$ March 2014. The nature of variables such as ROA, ROE, ROCE, ROS, and El was observed by using descriptive statistics and the result of changes in values of particular variables. The descriptive statistics covers minimum, maximum, mean, and standard deviation. In order to find the changes in values of El and profitability variables, the value of previous year was considered as the base.

The actual values of selected variables for the sample companies during the study period, were analysed to understand the nature of selected profitability variables and environmental performance of the firm. As pointed out earlier, four variables, namely, ROA, ROE, ROCE, and ROS were used under profitability variables (independent variables) while El was used as environmental performance variable (dependent variable). It is clearly understood from the Table that actual values of ROA were recorded as $0.0922,0.0992,0.1051,0.1164,0.1149,0.0949,0.0966,0.2047,0.10,0.0938$ and 0.1098 for the period 2004, 2005, 2006, 2007, 2008, 2009, 2010, 2011, 2012, 2013 and 2014 respectively. It is to be noted that the year 2011 earned the highest value of 0.2047 and the year 2013 received the lowest value of 0.0938 for the variable, ROA. Also, the value of ROE was the highest actual value $(0.2559)$ in 2007 and the lowest actual value (0.16127) in 2012. Further, the variable ROE recorded values of 0.2067 (in 2004), 0.2381 (in 2005), 0.2336 (in 2006), 0.2559 (in 2007), 0.2551 (in 2008), 0.2085 (in 2009), 0.2014 (in 2010), 0.1944 (in 2011), 0.1612 (in 2012), 0.1699 (in 2013) and 0.2126 (in 2014). In respect of ROCE, the Table reveals that actual values for ROCE were 0.14391 (in 2004), 0.17137 (in 2005), 0.17565 (in 2006), 0.18967 (in 2007), 0.1956 (in 2008) 0.16083 (in 2009), 0.16048 (in 2010), 0.15747 (in 2011), 0.13796 (in 2012), 0.13195 (in 2013) and 0.17659 (in 2014). However, the highest value for ROCE was 0.19560 in 2008 and the lowest value was 0.13195 in 2013 . The calculated actual value of ROS ranged from 0.10208 (2013) to 0.24082 (2008) during the study period. According to the results of the Table, the actual values of ROS were $0.10209,0.10826,0.12368,0.15045,0.24082,0.18369,0.13762,0.20479,0.11384,0.10208$ and 0.13557 in 2004, 2005, 2006, 2007, 2008, 2009, 2010, 2011, 2012, 2013 and 2014 respectively. Likewise, the actual values of El (dependent variable) were registered as 0.0428 in 2004, 0.414 in 2005, 0.0399 in 2006, 0.0385 in 2007, 0.0382 in 2008, 0.0411 in 2009, 0.0402 in 2010, 0.0406 in 2011, 0.0437 in 2012, 0.0458 in 2013, and 0.0497 in 2014. It is important to note from the analysis, as given in the Table that the maximum value $(0.0497)$ of El was recorded in 2014 and the minimum value (0.0382) was registered in 2008 during the study period.

The analysis of changes in actual values vividly demonstrates that the ROA showed positive values of 0.0070 in 2005, 0.0058 in 2006, 0.0113 in 2007, 0.0017 in 2010, 0.1081 in 2011, and 0.0159 in 2014. At the same time, in the years 2008, 2009, 2012, and 2013, the ROA recorded negative values as $-0.0015,-0.0199,-0.1047$ and -0.0062 respectively. Positive values were recorded in 2005 (0.0070), 2006 (0.0058), 2007 (0.0113), 2010 (0.0017), 2011 (0.1081) and $2014(0.0160)$ for ROE. Negative values of changes for ROE were recorded in $2008(-0.0015), 2009$ (- 
$0.0200), 2012(-0.1047)$ and 2013 (-0.0062). In the case of ROCE, its value changed positively as 0.0275 (2005), 0.0043 (2006), 0.0140 (2007), 0.0059 (2008) and 0.0446 (2014) while the negative values of changes for ROCE were identified as -0.0348 (2009), -0.0003 (2010), -0.0030 (2011), -0.0195 (2012) and -0.0060 (2013). The positive values of changes for ROS were 0.0062 in 2005, 0.0154 in 2006, 0.0268 in 2007, 0.0904 in 2008 and 0.0335 in 2014, but in the years 2009, 2010, 2012 and 2013, negative values of ROS were recorded as $-0.0571,-0.0461,-0.0909$ and -0.0118 . At the same time, negative values of El were recorded at $-0.0014,-0.0015,-0.0014,-0.0002$, and -0.0001 in 2005, 2006, 2007, 2008, and 2010 respectively. The El earned positive values as 0.0028 in 2009, 0.0005 in 2011, 0.0032 in 2012, 0.0021 in 2013, and 0.0038 in 2014.

From the Table, the results of descriptive statistics clearly showed the fact that the mean values of selected variables were 0.1231 (ROA), 0.2330 (ROE), 0.1816 (ROCE), 0.1637 (ROS), and 0.0459 (EI). The Table clearly shows that the minimum values were $0.0938,0.1613,0.1320,0.1021$ and 0.383 for variables, namely ROA, ROE, ROCE, ROS, and El respectively. During the study period, the maximum values of adopted variables were 0.2048 (ROA), 0.4009 (ROE), 0.3193 (ROCE), 0.2738 (ROS) and 0.0800 (EI). It is important to note from the results of Standard Deviation (SD), as given in the Table that the values of Standard Deviation (SD) were 0.0405 (for ROA), 0.0673 (for ROE), 0.0524 (for ROCE), 0.596 (for ROS), and 0.124 (for El) during the study period.

The interesting feature noted from the Table is that there was wide variation in the profitability variables (namely ROA, ROE, ROCE and ROS) and El. It is to be noted from the overall analysis of the Table that during the study period, except for the years 2010 and 2014, the dependent variable (EI) earned negative values while all the independent variables (ROA, ROE, ROCE, and ROS) recorded positive values. Hence this result shows the existence of inverse relationship between dependent variable (EI) and independent variables (ROA, ROE, ROCE, and ROS) in respect of sample firms during the study period.

Table - 2: Result of Descriptive Statistics, Actual value and Changes in selected Profitability variables and El of sample firms during the study period from 01-04-2005 to 31-03-2014

\begin{tabular}{|c|c|c|c|c|c|}
\hline \multirow[t]{3}{*}{ Variables } & \multicolumn{4}{|c|}{ Independent Variables } & \multirow{2}{*}{$\frac{\text { Dependent }}{\text { EI }}$} \\
\hline & ROA & ROE & ROCE & ROS & \\
\hline & \multicolumn{5}{|c|}{ Actual Value } \\
\hline 2004 & 0.0922 & 0.20675 & 0.14391 & 0.10209 & 0.0428 \\
\hline 2005 & 0.0992 & 0.23817 & 0.17137 & 0.10826 & 0.0414 \\
\hline 2006 & 0.1051 & 0.23364 & 0.17565 & 0.12368 & 0.0399 \\
\hline 2007 & 0.1164 & 0.25594 & 0.18967 & 0.15045 & 0.0385 \\
\hline 2008 & 0.1149 & 0.25512 & 0.19560 & 0.24082 & 0.0382 \\
\hline 2009 & 0.0949 & 0.20856 & 0.16083 & 0.18369 & 0.0411 \\
\hline 2010 & 0.0966 & 0.20148 & 0.16048 & 0.13762 & 0.0402 \\
\hline 2011 & 0.2047 & 0.19448 & 0.15747 & 0.20479 & 0.0406 \\
\hline 2012 & 0.1000 & 0.16127 & 0.13796 & 0.11384 & 0.0437 \\
\hline 2013 & 0.0938 & 0.16991 & 0.13195 & 0.10208 & 0.0458 \\
\hline 2014 & 0.1098 & 0.21263 & 0.17659 & 0.13557 & 0.0497 \\
\hline \multicolumn{6}{|c|}{ Changes in Actual value over the Previous Year } \\
\hline 2004 & - & - & - & - & - \\
\hline 2005 & 0.0070 & 0.0070 & 0.0275 & 0.0062 & -0.0014 \\
\hline 2006 & 0.0058 & 0.0058 & 0.0043 & 0.0154 & -0.0015 \\
\hline 2007 & 0.0113 & 0.0113 & 0.0140 & 0.0268 & -0.0014 \\
\hline 2008 & -0.0015 & -0.0015 & 0.0059 & 0.0904 & -0.0002 \\
\hline 2009 & -0.0199 & -0.0200 & -0.0348 & -0.0571 & 0.0028 \\
\hline 2010 & 0.0017 & 0.0017 & -0.0003 & -0.0461 & -0.0001 \\
\hline 2011 & 0.1081 & 0.1081 & -0.0030 & 0.0672 & 0.0005 \\
\hline 2012 & -0.1047 & -0.1047 & -0.0195 & -0.0909 & 0.0032 \\
\hline 2013 & -0.0062 & -0.0062 & -0.0060 & -0.0118 & 0.0021 \\
\hline 2014 & 0.0159 & 0.0160 & 0.0446 & 0.0335 & 0.0038 \\
\hline \multicolumn{6}{|c|}{ Descriptive Statistics } \\
\hline Mean & 0.1231 & 0.2330 & 0.1816 & 0.1637 & 0.0459 \\
\hline Minimum & 0.0938 & 0.1613 & 0.1320 & 0.1021 & 0.0383 \\
\hline Maximum & 0.2048 & 0.4009 & 0.3193 & 0.2738 & 0.0800 \\
\hline SD & 0.0405 & 0.0673 & 0.0524 & 0.0596 & 0.0124 \\
\hline
\end{tabular}

Note: El - Energy Intensity ROA - Return on Assets ROE - Return on Equity ROS - Return on Sales ROCE - Return on Capital Employed

Source: Compiled from Prowess and Computed using SPSS 20 \& Ms Excel 
The visual presentation, for the movements of changes in ROCE and El for the sample firms during the study period, is pictured in Chart - 1. The graphical representation helps to understand the changes in values of all the selected profitability variables (ROA, ROE, ROCE, and ROS) and El of the sample firms during the study period. To capture the accurate movements of lines, the Chart was drawn with two $Y$ axes (ie, left side and right side), and one $X$ axis. Left side $Y$ axis of the Chart reflects the changes of profitability variables while the right side $Y$ axis presents changes of $E$. The $X$ axis of the Chart stands for the year.

According to the Chart, the movements of profitability lines (for ROE, ROCE, and ROS) almost sloped down with minor changes during the period from 2005 to 2006. After that, the lines of ROE, ROCE, and ROS got picked up moderately to rise in the year 2007, and then the two lines such as ROE and ROCE started falling down immediately. At the same time, the ROS line continued its upward journey till 2008. But in 2009, all the lines of selected profitability variables (for ROE, ROCE, and ROS) touched the negative zone. But the line ROA which moved straight (without much change) in the positive zone from 2005 to 2008, and then it went down into negative zone in 2009. There was major upward direction of line from 2009 to 2011 for all the profitability variables. Once again, the line of profitability variables dropped down into the negative zone during 2012. At this point, line of ROS touched the depth of negative zone when compared to other selected profitability variables (ROA, ROE, and ROCE). Suddenly, the lines of all the selected profitability variables moved in the opposite direction (ie., upward direction) from 2012 to 2014 . It is interesting to note that all lines of selected profitability variables started and ended its journey in the positive zone of the Chart. As revealed by the Chart, the EA line commenced its journey with negative value and moved on a straight line (with thin variations) from 2005 to 2007. There was movement for El in the upward direction after the year 2007 and touched positive zone in 2009. But in 2010, El line dropped down suddenly into the negative zone. From 2012 to 2014, the El line moved in the upward direction and completed its movement in the positive zone.

It was observed from the Chart that during the study period, the lines of profitability variables and El moved in both negative and positive zones, with fluctuations (ups and down). It is interesting to note that in 2009, 2010, and 2011, the lines for both independent and dependent variables (profitability variables and $\mathrm{El}$ ) moved exactly in opposite directions which are decorated by arrows. Further, the Chart reveals that all the lines, both independent and dependent variables (profitability variables and EI), moved upwards together from 2013 to 2014 and such movements are marked by the dotted line, with oval arrow. The overall observation from the Chart confirms that the results of Chart are similar to the results of descriptive statistics. In other words, the results of Chart confirmed the results of descriptive statistics ie., there is a need for further examination to quantify the impact of profitability variables on El of the sample firms.

Chart - 1: Changes in Profitability and Energy Intensity of sample firms during the study period from 01-04-2005 to 31 03-2014

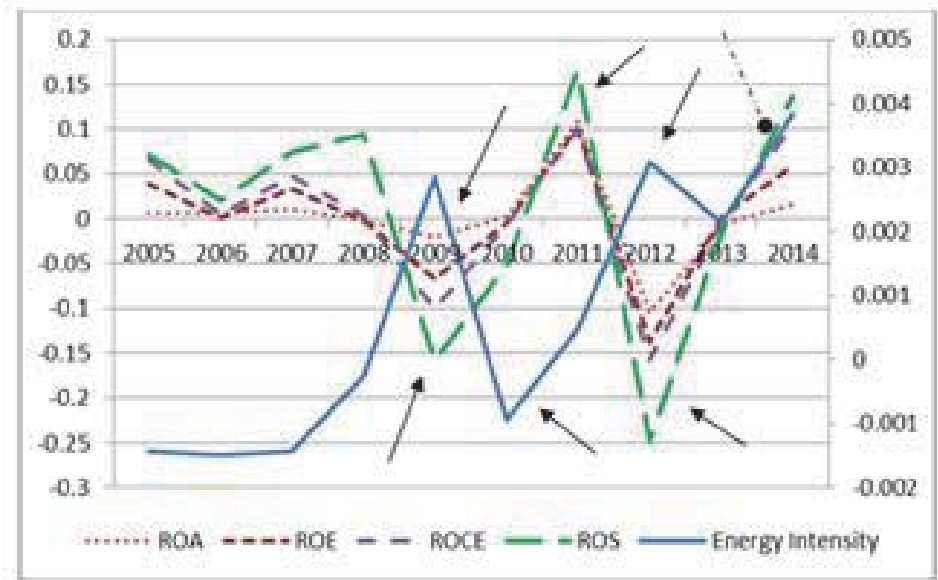

Source: Compiled from Table - 2 and using MS Excel

\subsection{Relationship among the selected profitability variables and El of sample firms}

Table -3 reports the results of correlation between the profitability and environmental performance of firms during the sample period from 01-04-2005 to 31-03-2014. By the results of the correlation analysis, the relationship of profitability variables (ROA, ROE, ROCE, and ROS) and El was examined. The linear relationship among the selected variables was 
examined to understand the relationship between profitability and environmental performance of firms. For the purpose of analysis, four sample profitability variables (ROA, ROE, ROCE, and ROS) were used as independent variables while only one variable (EI) was used as the dependent variable. The Table clearly shows that the values of correlation coefficient were recorded as -0.029 (for ROA - El), -0.131 (for ROE - El), -0.201 (for ROCE - El) and 0.016 (for ROS - El) during the study period. Likewise, profitability variables (ROA - ROE with the value of 0.231), (ROA - ROCE with the value of 0.284 ), (ROA - ROS with the value of 0.662 ) were positively correlated. Further, variables (set) such as ROE - ROCE (0.845), ROE - ROS (0.125), and ROCE - ROS (0.169) also earned positive values of correlation. Besides, the result of correlation vividly shows that two profitability variables (ROE and ROCE) were significant with El at $99 \%$ confidence level. At the same time, El with ROA and El with ROS were not significant at $1 \%$ level of significance. But all the four profitability variables (ROA, ROE, ROCE, and ROS) were highly significant among them at the same level (99\%) of confidence.

The overall analysis of the Table brings out the notable fact that majority of the sample variables (ROA, ROE, ROCE) recorded negative correlation with El (proxy of environmental performance) of the sample firms during the study period. However, positive correlation was found between one profitability variable (ROS) with El. Hence one can conclude that there was an increase (decrease) in the values of ROA, ROE, ROCE which tended to decrease (increase) the value of energy intensity. But there was direct relationship between ROS and El in respect of sample firms during the study period. In other words, every unit of increase (decrease) in ROA, ROE and ROCE may lead to decrease (increase) in El in respect of sample firms during the study period.

Table - 3: Result of Correlation for the Profitability and Environmental Performance (Energy Intensity) of sample firms during the study period from 01-04-2005 to 31-03-2014

\begin{tabular}{|c|c|c|c|c|c|c|}
\hline \multicolumn{2}{|l|}{ Variables } & \multirow{2}{*}{$\begin{array}{c}\text { Environmental Performance } \\
\text { (Dependent Variables) }\end{array}$} & \multicolumn{4}{|c|}{$\begin{array}{c}\text { Firms' Profitability } \\
\text { (Independent Variables) }\end{array}$} \\
\hline & & & ROA & ROE & ROCE & ROS \\
\hline $\begin{array}{c}\text { Environmental Performance } \\
\text { (Dependent Variables) }\end{array}$ & El & 1 & & & & \\
\hline \multirow{4}{*}{$\begin{array}{c}\text { Firms' Profitability } \\
\text { (Independent Variables) }\end{array}$} & ROA & -0.029 & 1 & & & \\
\hline & ROE & $-0.131^{\star *}$ & $0.231^{\star \star}$ & 1 & & \\
\hline & ROCE & $-0.201^{\text {** }}$ & $0.284^{\star \star}$ & $0.845^{\star \star}$ & 1 & \\
\hline & ROS & 0.016 & $0.662^{\star *}$ & $0.125^{\star *}$ & $0.169^{* *}$ & 1 \\
\hline
\end{tabular}

** Correlation is significant at the 0.01 level (2-tailed)

Note: El - Energy Intensity ROA - Return on Assets ROE - Return on Equity ROS - Return on Sales ROCE - Return on Capital Employed

Source: Compiled from Prowess and Computed using SPSS 20

\subsection{Impact of the selected profitability variables on El of sample firms}

The main objective of the paper was to study the impact of profitability and environmental performance of the sample firm. The results of regression for the profitability and environmental performance of the sample firms are summarized in Table - 4. The impact of profitability variables on environmental performance of the firms was tested by using the regression analysis.

From the results of the Table [ie., the value of t-statistic (2.731) and probability $(0.0064)$ ], it is clearly understood that the ROA exercised significant impact on El (Energy Intensity) during the study period. Also, it is to be noted that there was positive impact, with the coefficient value of 0.2815 . The values of $t-$ statistic and probability for ROCE were 9.095 and 0.0001 (less than the $1 \%$ significance value) respectively, which indicate that ROCE turned out to be significant with El. But the result of coefficient $(-0.7983)$ exposed the negative impact of ROCE on El. Likewise, ROA (0.2815), ROE (0.1992) and ROS (0.4486) were also found to have positive impact and significant association with El.

To test the fitness of the model for all independe $n t$ variables (jointly), $F$ statistic and $R$ square were used. It was identified that there was significant impact ( $F$ statistics -52.918 with $p$ value of 0.0001 ) of all the variables (ROA, ROCE, $\mathrm{ROE}$, and ROS). In other words, there was an influence of sample profitability variables on El. The overall model shows that $10.879 \%$ (R square value - 0.10879) variation of El was measured by this model. The result reveals that all the four independent variables (ROA, ROCE, ROE, and ROS) showed significant result. From this, it is inferred that the model was good to test the influence of profitability on El. The result of Durbin - Watson stat also supported this model with a 
value of around 2 (1.856). This further confirmed that the model was good and the variables were independently distributed. Hence the Null Hypothesis ( $\mathrm{NH} 1)$, there is no impact of profitability variables on environmental performance of the firm, is rejected. In other words, there was impact of profitability variables on the environmental performance of the firm during the study period. From the results of the Table, the equation was framed to evaluate the Energy Intensity $(\mathrm{EI})$, as El $=(0.2815) \mathrm{ROA}+(-0.7983) \mathrm{ROCE}+(0.1992) \mathrm{ROE}+(0.4486) \mathrm{ROS}+(-1.7475)$.

Table - 4: Result of Regression for the Profitability and Environmental Performance (Energy Intensity) of sample firms during the study period from 01-04-2005 to 31-03-2014

\begin{tabular}{|c|c|c|c|c|}
\hline Variable & Coefficient & Std. Error & t-Statistic & Prob. \\
\hline ROA & 0.281479 & 0.103075 & 2.730815 & $0.0064^{* \star}$ \\
\hline ROCE & -0.798308 & 0.087778 & -9.094601 & $0.0001^{\text {*x }}$ \\
\hline ROE & 0.199212 & 0.085807 & 2.321635 & $0.0204^{\star \star}$ \\
\hline ROS & 0.448612 & 0.052402 & 8.561016 & $0.0001^{* *}$ \\
\hline$C$ & -1.747488 & 0.052628 & -33.20466 & $0.0001^{\text {*x }}$ \\
\hline \multicolumn{3}{|l|}{ F-statistic } & \multicolumn{2}{|c|}{52.91791} \\
\hline \multicolumn{3}{|c|}{ Prob(F-statistic) } & \multicolumn{2}{|c|}{$0.0001^{\star \star}$} \\
\hline \multicolumn{3}{|c|}{ R-squared } & \multicolumn{2}{|c|}{0.108791} \\
\hline \multicolumn{3}{|c|}{ Adjusted R-squared } & \multicolumn{2}{|c|}{0.106735} \\
\hline \multicolumn{3}{|c|}{ Durbin-Watson stat } & \multicolumn{2}{|c|}{1.856011} \\
\hline
\end{tabular}

**significant at the 0.01 level

Dependent Variable: Environmental Performance (Energy Intensity)

Note: ROA - Return on Assets ROE - Return on Equity ROCE - Return on Capital Employed ROS - Return on Sales

Source: Compiled from Prowess and Computed using E-Views 7.1

On the basis of the regression coefficient, the impact of ROA, ROE, ROCE, and ROS on El is displayed in Figure -1. It is clearly seen that all the selected variables recorded significant impact on El. Further, the positive impact is indicated by solid arrow while the negative impact is indicated by dash arrow. The Figure indicates that all variables, namely, ROA, ROE, ROS recorded positive impact on El except one sample variable, ROCE, in respect of sample firms during the study period.

Figure - 1: Model showing the Impact of selected Profitability variables on Energy Intensity

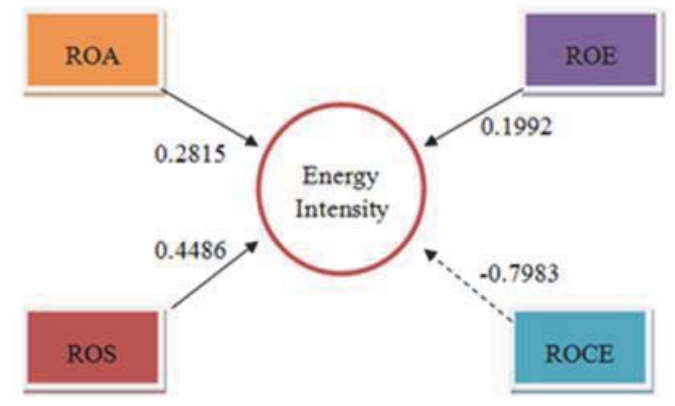

Source: Developed from Table - 4

Note: Positive Impact -

Negative Impact -

\section{Findings, Conclusion and Scope for Further Research}

\subsection{Findings and Conclusion}

The relationship and impact of profitability variables on the firm's environmental performance was measured by using Correlation and Regression analysis. It was found that there was negative relationship between firms' profitability variables and environmental performance of the firm expect in the case of the variable, ROS. The variable, namely, ROS 
recorded positive relationship between environmental performances of the firm. It implies that profitability variables recorded inverse relationship with El. That is, increase in the level of ROA, ROE, and ROCE leads to decrease in the level of energy intensity. To predict the environmental performance of the firm, the model was framed by the regression analysis. It shows that $10.879 \%$ variation of El was measured by this model. It was observed that there was significance between the profitability of the firm and the firm's environmental performance during the study period. In the regression model, one variable, namely, ROCE recorded negative impact on environmental performance and the equation was framed as El $=(0.2815) \mathrm{ROA}+(-0.7983) \mathrm{ROCE}+(0.1992) \mathrm{ROE}+(0.4486) \mathrm{ROS}+(-1.7475)$.

From the overall result, it can be concluded that profitability variables of the firm (ROA, ROE, ROCE, and ROS) registered significant impact on environmental performance. The findings of this study are in line with the findings of G.Y. Qi et al (2014) \& Russo and Fouts (1997) who found that there was a significant relationship between the financial performance of the firm and environmental performance. At the same time, the results of this study differ with the result of Aly Salama (2005).

\subsection{Research Implication}

This study would help the corporate managers, policy makers and regulators to take appropriate decision about the environmental performance of the firm. By concentrating on the leading indicators, the environmental performance of the firm can be managed. The appropriate policy should be framed to increase the level of environmental performance by the Indian firms.

\subsection{Scope for Further Research}

This study mainly focused on the impact of profitability variables on environmental performance of the firm. The profitability of the firm was measured only by selected variables like ROA, ROE, ROCE, and ROS. In future, a similar study may be carried out by considering some other variables like stock market performance variables, liquidity, leverage ratios of the company etc. Likewise, econometric tools like Granger Causality may be used to examine the bi directional relationship between the variables. The sample selection of the company may be extended to all companies in India.

\section{References}

Aly Salama (2005). A note on the impact of environmental performance on financial performance. Structural Change and Economic Dynamics, 16, 413-421.

Amy Tung, Kevin Baird, Herbert Schoch (2014). The relationship between organisational factors and the effectiveness of environmental management. Journal of Environmental Management, 144, 186 - 196.

Cormier,D. and Magnan, M. (2003). Does disclosure matter? CA magazine. May: 43-50. Retrieved from http://www.camagazine.com/ archives/printedition/2003/may/regulars/ camagazine23446.aspx (August 20, 2014).

David I. Stern, Michael S.Common and Edward B.Barbier (1996). Economic Growth and Environmental Degradation: The Environmental Kuznets Curve and Sustainable Developmnet. World Development, 24 (7), 1151 - 1160.

Elif Akbostanci, Serap Turut Asik G and Ipek Tunc (2009). The Relationship between income and environment in Turkey: Is there an environmental Kuznets curve?. Energy Policy, 37, 861 - 867.

G.Y.Qi, S.X.Zeng, Jonathan J.Shi, X.H.Meng, H.Lin and Q.X.Yang (2014). Revisiting the relationship between environmental and financial performance in Chinese industry. Journal of Environment Management, 145, 349 - 356.

Goldar, B., (2010). Energy Intensity of Indian Manufacturing Firms: Effect of Energy Prices, Technology and Firm Characteristics. Working Papers, id-2483. eSocialSciences

Hart, S.L., Ahuja, G., (1996). Does it pay to be green? An empirical examination of the relationship between emission reduction and firm performance. Business Strategy and the Environment, 5, 30-37.

Hiroki Iwata and Keisuke Okada (2011). How does environmental performance affect financial performance? Evidence from Japanese Manufacturing firms. Ecological Economics, 70, 1691 - 1700

Khalid Ahmed and Wei Long (2012). Environmental Kuznets Curve and Pakistan: An Empirical Analysis. Procedia Economics and Finance, 1, 4-13.

Marcus Wagner, M., (2005). How to reconcile environmental and economic performance to improve corporate sustainability: corporate environmental strategies in the European paper industry. Journal of Environmental Management, 76, 105-118.

Mark A. Cohen Scott and A. Fenn. Shameek Konar (1997). Environmental and Financial Performance: Are They Related?. retrived from http://sitemason.vanderbilt.edu/files/d/dLwFkQ/Environmental\%20and\%20Financial\%20Performance.pdf. (February 15, 2014).

Priyanka Aggarwal (2013). Relationship between Environmental Responsibility and Financial Performance of Firm: A Literature Review. IOSR Journal of Business and Management, 13 (1), 13 - 22

Ruchika Bammi (2013). An Empirical Analysis of Environmental and Financial Performance of BSE 100 Companies. Indian Journal of 
Finance. 7 (6): 16- 30.

Russo, M., Fouts, P., (1997). A resource-based perspective on corporate environmental performance and profitability. Academy of Management, 40, 534-559.

Santhosh Kumar Sahu and Krishnan Narayanan (2011). Determinants of Energy Intensity in Indian Manufacturing Industries: A Firm Level Analysis. Eurasian Journal of Business and Economics, 4 (8), 13 - 30.

Stern, P. C. (1992). Psychological dimensions of global environmental change. Annual Reviews of Psychology, 43, 269 - 302.

Toshiyuki Sueyoshi and Mika Goto (2009). Can environmental investment and expenditure enhance financial performance of US electric utility firms under the clean air act amendement of 1990?. Energy Policy, 37, $4819-4826$. 